\title{
ISLAM POLITIK DI PAPUA: RESISTENSI DAN TANTANGAN MEMBANGUN PERDAMAIAN
}

\author{
Idrus Al-Hamid
}

Sekolah Tinggi Agama Islam Al-Fatah Jayapura

Email: idrusalhmd@yahoo.com

\begin{abstract}
This paper reflects the present of political Islam and Cultural Islam in recent Papua. The two groups of Islamic movements sign that number of Moslem population is growing in line with the coming of the Moslem immigrant from other areas of Indonesia. The consequences are facilities such as mosques, Iskamic institutions, Islamic schools/educations are increasing. The Papuan Moskem Assembly which represents the indigenous moslem onganizations discourages the newly came Islamic onyaniqutions such as Hizbut Tabrir Indonesia (HTT), Salafi, even Lasker Jibad, to utilize the bardline links and teachings in preaching (dakwab). From the encounter side or non Muslim, indigenous Papua and particularly Christian that phenomena leads to the "Islamization" which is waming of the peace building. This paper also suggests to create a friendly teachings/mission and to move closely the dakwah into the local/indigenous people witbin community. The diversity of Papuan identity calls the Islamic preachers to bave more respects and cultural understanding during the teachings.
\end{abstract}
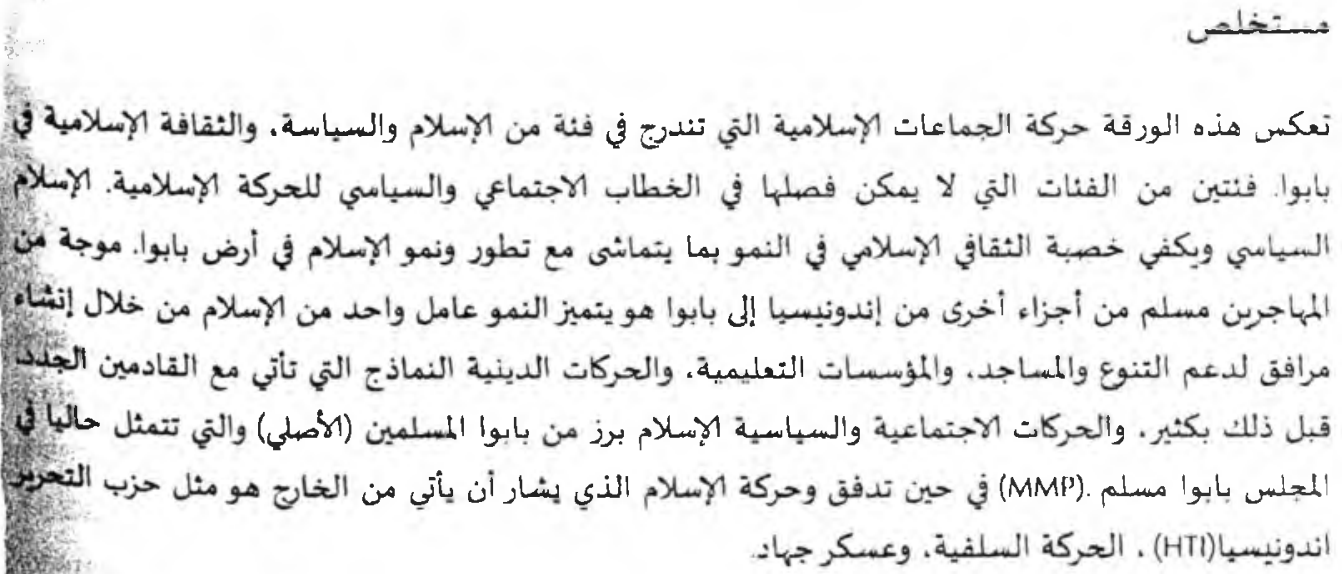

Kymords: Political Islam, Cultural Islam, Papua, Peace building 


\section{A. Pendahuluan}

Tak dipungkiri, hingga saat ini benih konflik dan persinggungan di tanah indah cendrawasih ini masih ada. Perselisihan masih kerap terjadi di antara berbagai pihak, baik antar kelompok suku, antar kelompok yang diamdiam atau secara vulgat mendukung KNPB Papua dengan pemerintah pusat RI, juga warga yang menamakan diri sebagai pribumi Papua dengan warga yang dianggap pendatang. Ada pula warga Papua yang mengelompokkan warga Papua ke dalam posisi yang berlawanan antara masyarakat pesisir dan masyarakat pegunungan. Dua kategori kelompok terakhir ini juga sering diidentikkan dengan warga pegunungan sebagai pribumi Papua dan Pesisir sebagai Non-Pri Karena telah terjadi pembaurang.

Kesenjangan sebagai efek lain dari upaya pembangunan yang menghasilkan kelompok masyarakat mampu dan tidak mampu juga salah satu faktor berseminya benih-benih konflik dan perselisihan. Kata pembangunan sendiri menjadi semacam gerakan ideologis dari pemerintah pusat untuk melakukan penetrasi ide-ide Negara Kesatuan Republik Indonesia (NKR). Sementara masih ada kelompok masyarakat Papua yang tetap memimpikan kemerdekaan Papua. Di masyarakat Papua berkembang pengelompokkan atas dasar orientasi politik ini dengan menyebut kelompok nasionalis yang pro kemerdekaan dengan Merah Sekali (MS), dan kelompok nasionalis Indonesia yang pro NKRI disebut Biru Sekali (BS). Kubu MS memiliki turunan kelompok warga dari OPM (Organisasi Papua Merdeka), TPN (Tentara Pembebasa Nasional), PDP (Presidium Dewan Papua) dan kelompok lainnya. Sementara kubu BS terdiri dari TNI, Polri, Barisan Merah Putih, Milisi Laskar Jihad dan Kerukunan Keluarga Sulawesi Selatan (KKJS).

Proses pembangunan di Papua pada praktiknya dipenuhi dengan banyak konflik dan sensitif terhadap berbagai isu yang memicu konflik. Sensitivitas Papua sebabgai bagian NKRI dimulai dari mitos Papua Propinsi yang khas dan berbeda. Orang cenderung mengingat kekhasan Papua dengan warna kulit, bentuk rambut serta semua sistem adat istiadatnya sebagai hal yang primitive dan uncivilized. Konsekuensinya, kata "pembangunan" di Papua sarat dengan politik civilization (pemberadaban). Hampir semua mekanisme dan bidang 
modern masuk di Papua dengan tujuan meningkatkan kualitas hidup, mulai dari kondisi struktur sosial yang mencakup persoalan akses media. Kesehatan, pendidikan, transportasi, lingkungan hingga soal ekonomi. Masyarakat Papua, terutama yang disebut sebagai "penduduk asli", seolah menjadi manusiamanusia yang sepenuhnya dijadikan objek (Imarotus, 2011, 277).

Hubungan Papua dengan pemerintah pusat masih menyisakan persoalan bagi sebagian masyarakat Papua. Hal ini bisa saja sewaktu-waktu memunculkan konflik baru rasa lama selama masih ada kelompok-kelompok yang punya orientasi pada kemerdekaan. Proposal penerapan Otonomi Khusus Papua didasarkan pada perasaan termarginalkan, terjajah, dan berada dibawah tekanan pemerintah pusat selama empat dekade. Selama persoalan ini tidak terjawab oleh pemerintah pusat dan membuat masyarakat Papua puas, benih konflik masih ada. Di sisi lain, identitas etnis yang muncul dengan rasa nasionalisme Papua menyisakan paradox dan ironi. Pertama, orang Papua identik sebagai oposisi terhadap pemerintah pusat, Papua sendiri terdisir dari hampir 310 kelompok etnik-bahasa. Keberagaman ini juga menghadirkan tantangan tersendiri dalam membangun nasionalisme orang Papua'. Kedua, pembentukan identitas Papua lebih umum dipandang sebagai rival terhadap Pemerintah Pusat dan tidak memiliki kebersamaan nilai dengan daerah atau etnis tetangganya seperti Bugis, Makassar, atau Maluku. Papua kurang memiliki perasaan bersama secara kultural, dan pengalaman sejarah. Ketiga, bahasaa Melayu/Indonesia sudah menjadi bahasa baik bagi Papua maupun Indonesia. Sejak zaman kolonial, Orang Belanda mengajarkan bahasa Melayu sebagai pengantar pergaulan dan misi. Beberapa hal diatas menimbulkan kegalauan dalam pembentukan identias Papua.

Sementara dalam Undang-undang Otonomi Khusus Papua tatun 2001 orang Papua asli diidentikkan dengan orang dari kelompok Melanisia atau imigran yang telah diakui dan diterima sebagai kelompok etnis di Papua. Bagaiamanapun dalam realitasnya, penduduk papua dibagi berdasarkan tiga kelompok pemeluk agama yaitu Kristen, Katolik, dan Muslim. Yang terjadi

\footnotetext{
' Richard Chauvel, Constructing Papuan Nationalism, History, Ethnicity and Adaptation, Policy Studies 14, East-West Center Washington, 2005.
} 
dalam debat soal identitas Papua adalah antara Muslim Papua dan Kristen Papua. Perbedaan tafsir soal identitas Papua yang dikonstruksikan oleh kalangan ilmuwan dan elit Papua seiring dengan wacana re-papuanisasi. Persinggungan ras, pengelompokkan etnik dan agama menjadi relevan dalam rancangan Oronomi Khusus. Dalam konteks ini, kelompok muslim mempertanyakan asumsi dan klaim bahwa Papua asli adalah beragama Kristen².

Perkembangan Islam politik (Islamisme) di dalam kontestasi demokrasi Indonesia pasca reformasi yang maju cukup signifikan dan mewarnai gerakan agama dan sosial pada umumnya. Salah satu model gerakan Islamisme yang marak di era reformasi adalah upaya konstitusionalisasi dan institusionalisasi paham keagamaan dalam ranah publik melalui desakan dan penerapan Rancangan Peraturan Daerah (Raperda) yang berbasis nilai syariah Islam. Penerapan Syariat Islam di Nangreo Aceh Darussalam juga berimplikasi pada munculnya keinginan dan dorongan di daerah-daerah lain untuk melakukan hal serupa. Hal ini tercermin dari sentiment dan wacana yang muncul di Manokwari yang memunculkan ide Manokwari sebagai Kota injil melalui Rancangan Peraturan Daerah tahun 2006.

Dalam beberapa kasus konstitusionalisasi ini dijadikan komoditas politik dan kekuasaan, misalnya, betapa getolnya beberapa provinsi yang mayoritas penduduknya (Aceh, Gorontalo, Banten, NTB dan beberapa provinsi lainnya) dalam segi jumlah (kuantitas) memeluk agama Islam, mengeluarkan peraturan Daerah (Perda) yang sangat jelas momihak agama Islam. Reaksi beberapa daerah lain yang juga mayoritas penduduknya memeluk Kristen juga untuk melakukan hal yang sama. Selain Papua, juga di Malukuyang berencana mengeluarkan perda Injil sebagai imbangan atas keluarnya Perda Syariah di daerah yang mayoritas beragama Islam tersebut. Jika ditelisik lebih dalam para pembuat dan inisiator kebijakan tersebut hampir pasti akan menyatakan bahwa keputusantersebut untuk melindungi akidah masyarakat yang mayoritas.

2 Cahyo Pamungkas, Muslim Papua and Special Autonomy: The Identity Contest in Papua, Journal of Indonesian Social Sciences and Humanities Vol. 4, 2011, pp. 133-155 URL: http:/ / www,kitlv-journals.nl/index,php/iissh/index 
Organisasi Islam semacam Nahdlatul Ulama dan Muhammadiyah sudah berada lama di Papua, begitu pula cabang- cabangnya. Demikian juga Partai yang berlandaskan Islam seperti Partai Keadilan Sejahtera memiliki pengurus cabang dan daerah. Namun dalam beberapa tahun terakhir, diakui bahwa beberapa kelompok dan aliran Islam yang lain seperti Salafi, Jama'ah tabligh dan Laskar Jihad telah hadir di beberapa daerah di Papua.

\section{B. Wacana Islam Politik dan Benih Konflik}

Ada banyak pandangan teori perihal kedatangan Islam di Papua. Pelaut Spanyol, Louis vas de Torres dalamperejalanannya ke Papua pada abad ke 14 menemukan para pedagang dari Makassar, Ternate dan Tidore mengajarkan Islam sambil berdagang di Onim, Fak-fak. Kesultanan Bacan dari Maluku Utara pada abad 16 diketahui telah menduduki beberpa wilayah Papua Barat sepcri Waigeo, Misool, Waigama dan Salawati. Pada abad ke 15 juga diketahui bahwa rakyat Papua di kawasan pantai utara dan Barat kehilangan kedaulatannya ketika kesultanan Tidore datang dan melakukan pendudukan. Islam diyakini sebagian kalangan sebagai agama asing pertama yang datang ke Papua. Namun perannya dalam memberikan kontribusi terhadap bangunan peradaban Papua sangat terbatas karena Islam pada awalnya tidak dibawa oleh organisasi dakwah keagamaan melainkan oleh perseorangan melalui para pedagang dan pelaut.

Islam politik diidentikan dengan aktivisme Islam yang di wacana Barat disebut Islamism, memiliki jangkauan makna yang sangat luas. Namun Islam politik dipicu oleh munculnya berbagai macam gerakan perjuangan Islam di berbagai negara yang intinya adalah mobilisasi perseteruan untuk mendukung kepentingan dan tujuan kaum muslim terhadap dominasi, imperialis dan Barat pada umumnya. Aktivisme Islam, nama lainnya, awalnya muncul dari posisi kaum muslim yang berada dalam tekanan kelompok atau kondisi terpinggitkan sehingga muncul gerakan perlawanan. Namun, secara umum aktivisme Islam mencakup beragam perseteruan yang seringkali muncul atas nama Islam, termasuk gerakan-gerakan dakwah, kelompok-kelompok teroris, tindakan kolektif yang bersumber dari symbol dan identitas Islam, gerakan-gerakan politik yang berusaha mendirikan negara Islam, dan kelompok-kelompok 
berorientasi ke-dalam yang mengusung spiritualisme Islam dengan usaha-usaha kolektif (Wiktorowicz, 2012, 38).

Sementara Islam Kultural menurut Dawam Raharjo adalah sebuah kategori yang relative baru dan muncul di Indonesia sekitar tahun 80-an, namun sebagai wacana sudah lama ditengarai. Islam kultural sudah muncul sejak awal perkembangan Islam itu sendiri sebagai agama di tanah kelahirannya. Ia bisa ditafsirkan sebagai suatu gejala sosiologis, bisa juga sebagai aliran keagamaan. Lebih sering ditafsirkan sebagai kedua-duanya, gejala sosiologis dan teologis sekaligus. Sebagai istilah, Islam Kultural sering dilawankan dengan Islam Politik. Dua kategori ini di Indonesia sudah lama diperbincangkan sejak gerakan Islam muncul di masa Orde Baru' ${ }^{3}$.

Situasi di Papua dalam sepuluh tahun terakhir mendorong adanya model aktivisme Islam di beberapa daerah, kabupaten/kota. Hal ini sangat mungkin dipengaruhi oleh konstelasi perubahan sosial politik nasional Indonesia dan politik lokal, perkembangan keagamaan di Papua dan relasi-relasi antar kelompok sosial dan agama. Dalam beberapa hal, muslim Papua yang merupakan minoritas di Papua merasakan tekanan, meskipun di sisi lain, saat ini ada gejala pertumbuhan karena banyaknya imigtan yang dianggap mendapat sokongan dari orang luar Papua. Sensus tahun 2006 menyebutkan bahwa penduduk Muslim Papua mencapai angka $14 \%$ dari jumlah populasi warga Papua, $55 \%$ lainnya menganut Kristen, 30\% Katolik, sisanya ada yg menganut Buddha dan Hindu. Mayoritas Muslim Papua berasal dari kalangan imigran yang berawal dari hasil program transmigrasi, dan juga berasal dari jalur perdagangan dan nelayan dari Buton, Bugis dan Makassar.

${ }^{3}$ Dawam Rarjo menyebutkan, Islam Kulutral diambil dari bahasa Arab Al-Islam al Siyasi dan dalam bahasa Inggris menjadi Political Islam. Pertama kali diperkenalkan oleh pengikut pemikir muslim sekuler Ali Abd. Al Razik, Muhammad Sa'id al Ashmawi. Ashmawi menulis buku Against Islamic Extremism untuk mengkritik pandangan Islam Ekstrim dimana ia mendefinisikan Islam Politik sebagai Islam Ekstrim, yaitu aliran Islam tekstual ortodoks yang beroricntası pada paham Islam di awal perkembangannya atau paham Islam tradisional yang dianggap baku dan sudah selesai karena itu harus dikuti dengan cara taklid. Kata Pengantar M. Dawam Raharjo dalam Islam Kultural Dalam Perspel:tif Reformasi, dalam Artikulasi Islam Kultural, Dari Tahapan Moral ke Periode Sejarah, RajaGrapindo Jakarta, 2004 hal. v-vii 
Dalam beberapa kondisi, gerakan model fundamentalis dimasukkan dalam Islam politik atau aktivisme Islam ini. Fundamentalisme dipahami sebagai gerakan keagamaan yang menuntut perlunya kembali pada ajaran agama yang asli seperti yang tersurat dalam kitab suci dan sebagiannya cenderung memperjuangkan keyakinannya secara radikal. Beberapa cirri fundamentalisme agama antara lain cenderung menafsirkan teks-teks keagamaan secara rigid dan literalis (tekstual), cenderung memonopoli kebenaran atas tafsir agama (menganggap dirinya/kelompoknya paling abash), sehingga menganggap paham di luar kelompoknya sebaga paham sesat, meniscayakan hubungan yang harmonis antar agama dan negara, memiliki pandangan yang stigmatis terhada Barat, menolak sekularisme, memiliki kecenderungan melakukan aksi kekerasan dalam memperjuangkan nila yang dipahaminya ${ }^{4}$.

Contoh pengaruh luar Papua antara lain munculnya seruan-senuang kelompok Islam tertentu semacam Front Pembela Islam yang bersuara dari Jakarta akan mengirim lascar jihad ke Papua guna ikut mempertahankan NKRI dan mencela gerakan dan organisasi separatis Papua. Rencana serupa juga dilakukan untuk ke Maluku yang dianggap masih terdapat gerakan separatis (RMS). Dalam analisis wacana gerakan Islam, organisasi semacam FPI, Salafi, Laskar Jihad dan HTI dimasukkan dalam model gerakan fundamentalis.

International Crisis Group (ICG) pada laporan edisi Juni 2008 mencatat dalam 10 tahun terakhir model organisasi keagamaan radikal telah masuk dan berkembang di Papua. Bukan hanya ormas radikal muslim, namun juga dari kalangan radikal Kristen (pentakosta-Kharismatik/evangelis). Organisasi Hizbut Tahrir (HTI) dan kelompok aliran Salafi mulai memberikan warna dalam gerakan Islam yang selama ini didominasi oleh Nahdlatul Ulama dan Muhammadiyah yang merupakan golongan moderate. Sementara, gerakan Neo Pentekostal melihat dakwah Islam sebagai tantangan besar di lahan Papua.

4 Lihat Martin E. Marty dan R. Accot Applebey, Fundamentalism Comprehended, Chicago; the University of Chicago Press, 1995 dan Abdurrahman Kasdi, "Fundamentalisme Islam Timur Tengah: Akar Teologi, Kritik Wacana, dan Politisasi" dalam 'lashwirul Afkar, Jurnal Refleksi Pemikiran Keagamaan dan Kebudayaan, edisi No 13 tahun 2003, hal. 322. 
Pertemuan dua kelompok militant keagamaan ini menimbulkan potensi ketegangan yang cukup besar ${ }^{5}$.

Studi kasus mengenai masjid dan pembangunan perdamaian di masjid raya Baiturrahim Jayapura menunjukkan adanya kontestasi antar kelompok aliran Islam yang memberikan ajaran dan pengaruhnya di Jayapura. Kelompok Hizbut Tahrir, Salafi, Jamaah Tabligh, Muhammadiyah dan Nahdlatul Ulama bergantian menghadirkan pengajian dan pengajaran di masjid ini. Kasus ini mengkonfirmasi adanya kelompok-kelompok Islam luar yang punya kecenderungan militan ${ }^{6}$. Sementara Majlis Muslim Papua yang selama ini merepresentasikan muslim lokal Papua bersama NU berupaya mengawasi penggunaan Islam sebagai komoditas dan sentiment penyebaran anti Islam itu sendiri.

Dalam studi kasus di masjid Baiturrahim, kelompok Islam yang dikategorikan fundamentalis seperti Salafi, Jama'ah Tabligh, dan HTI tidak secara vulgar menunjukkan agresivitas dakwah yang keras. Mereka cenderung lebih lunak dibanding gambaran gerakan dakwah mereka di tempat lain di Indonesia. Mereka memahami sensitivitas dan realitas lapangan dakwah mereka di Papua. Bahkan, HTI dalam bulletin yang Al Islam yang sering dijumpai di Masjid itu banyak memunculkan tema-tema kritis terhadap pemerintah dan anti demokrasi. Persepsi atas konsep Jihad, seperti yang diungkapkan salah seorang da'l Salafi lebih berorientasi dakwah/jihad bilhal, yaitu melalui contoh teladan, dan mengajarkan Islam yang prinsipil. Meskipun dalam beberapa hal, misalkan penampilan jamaah di sekitar masjid banyak yang menggunakan pakaian ala Jama'ah Tabligh dengan gamis panjang dan pakaian tertutupnya.

Keberadaan organisasi Hizbut Tahrir Indonesia (HTI) diketahui mulai masuk kira2 tahun 2000-an dengan membuka cabang di Jayapura melalui para pendatang dari Jawa dan Makassar yang datang ke Papua sebagai pekerja. Aktivis mahasiswa HTI juga diketahui telah mendirikan organisasi Gerakan

${ }^{5}$ International Crisis Group (ICG), Indonesia; Communal Tensions in Papua, Asia Report No 154-Junc 162008 , hal. 1

${ }^{6}$ Lihat Nur Imarotus S. , Yang Radikal dan Yang Moderat di Papua; Membangun Institusi Perdamaian di Masjid Raya baiturrahman Jayapura, dalam Masjid dan Pembangunan Perdamaian, editor Ridwan Al Makassary dkk., (CSRC UIN Jakarta 2011) hal. 293. 
Mahasiswa Pembahasan. Indikasi lain mengenai aktivitas HTI di Jayapura adalah adanya sekitar 300 orang wakil HTI dari Papua yang mengikuti konferensi Khalifah intemasional di Jakarta pada tahun 2007. Target dakwah HTI bukan hanya kalangan pendatang namun juga dari Muslim Papua (asli) seperti dari Fak-fak dan beberapa daerah lain. HTI Jayapura diketahui sering melakukan aksi demonstrasi terkait isu-isu global Islam, anti kolonialisme, kenaikan harga BBM, dan anti separatisme.

Sementara itu golongan Salafi mulai dikenal di Papua melalui suara dan pembicaraan Ja'far Umar 'Thalib pemimpin gerakan salafi dan dengan milisi Laskar Jihad mulai tahun 2002. Salafi tampaknya tidak terlalu cepat perkembangannya seperti HTl. Kegiatannya lebih banyak ke pengajian dan pendidikan dasar dan jarang sekali mengangkat isu tentang orang lokal Papua sebagai komoditas gerakannya. Juga di Jayapura, kelompok Jama'ah Tabligh banyak melakukan pengajian-pengajian umum. Pengaruh gerakan dari Jama'ah Tabligh menarik sebagian orang Papua (asli) untuk bergabung. Pada penampilan pengikut dan simpatisannya menyerupai jama'ah tabligh lainnya?

Saya memandang bahwa pergerakan dakwah Islam sendiri harus lebih luas dengan memperkenalkan Islam yang tidak keras. Dalam arti, tetap menghargai dan bertoleransi pada kebiasaan masyarakat lokal selama tidak bertentangan akidah dasar keislaman. Tantangan yang dihadapi selama pembangunan STAIN Al-Fatah sendiri cukup berat dimana sejak awalnya muncul penolakan dari sebagian kelompok masyarakat. Penampilan juga tidak harus diidentikkan dengan kelompok tertentu melainkan tetap sederhana dan wajar saja.

Gejala disharmonisasi masih cukup mengkhawatirkan dan laporanlaporan gerakan eksklusif cenderung membesar dan bisa menyebabkan potensi disharmoni, khususnya dalam hal agama (Islam - Kristen) membesar. Dari pihak Kristen, mereka khawatir karena melihat perkembangan institusi-institusi pendidikan Islam semakin menjamur dan secara ekonomi warga muslim khususnya di daerah kota di Papua ini dipandang cukup baik. Sementara klaim

\footnotetext{
'Lihat laporan dari Asia Report berjudul "Indonesia Communal Tensions in Papua", edisi 154-16 Juni 2008 p.16-17
} 
bahwa masyarakat Papua adalah mayoritas beragama Kristen dan Kristen sebagai agama asli orang Papua. Namun, sebenarnya baik Islam maupun Kristen memiliki agenda dan jalan yang sama dalam menjalankan misinya. Di kalangan Kristen, munculnya gerakan kelompok Kristen neo pantekostal yang eksklusif dan gencar melakukan evangelisasi juga mendorong Islam-Kristen pada posisi berhadap-hadapan.

Islamisasi merupakan isu yang selama ini menjadi salah satu hal yang mendapat perhatian cukup keras. Hal ini ditengarai dari bertumbuhnya kegiatan Islam, lembaga Islam, dan organisasi muslim dalam satu decade terakhir. Bagi kalangan Kristen, fakta ini sianggap sebagai sebuah peringatan dan persinggungan kepentingan penyebaran agama ini memunculkan isu islamisasi sebagai bentuk yang diwaspadai kalangan Kristen.

Isu Raperda tentang rencana menjadikan Manokwari sebagai kota Injil sempat memanas mulai tahun 2006 dan masih hangat dibicarakan sampai sekarang. Raperda itu disinyalir sebagai imbas pemberlakuan syari'at Islam di Aceh. Di kawasan timur, Sulawesi Selatan juga gencar mewacanakan otonomi khusus dengan tuntutan penerapan syari'at Islam-nya. Am. Fatwa menuturkan, secara definisi, teori dan penjabarannya syariat Islam masih problematis. Pelaksanaan syariat Islam juga memunculkan kecurigaan ideologis dan motif politik baik dari intern Islam sendiri maupun dari luar Islam. Misalnya saja ada anggapan bahwa kalau syariat Islam diberlakukan akan terjadi disintegrasi bangsa atau akan membuat masyarakat menjadi monolit ${ }^{8}$. Dalam konteks ini, wajar jika Isu Raperda ini mendapat tanggapan reaktif dari kawasan yang mayoritas bukan muslim semisal Papua. Raperda ini pula diwacanakan bersamaan denganisu penolakan pembangunan masjid Raya Manokwari yang diduga akan dijadikan Islamic Center. Alasan penolakan pembangunan Masjid Raya ini diwarnai

Laporan International Crisis Group tanggal 16 Juni 2008 yang dapat dijadikan Early Warming Sistem tentang masalah kerukunan antarumat beragama

${ }^{8}$ Lihat A.M Fatwa, Syariat Islam, Otonomi Khusus danMasa Depan Masyarakat Sulawesi Selatan, dalam Syariat Islam Yes, Syariat Islam No, Dilema Piagam Jakarta dalam Amandemen UUD 1945, editor Kurniawan Zen dkk. Paramadina Jakarta, hal.173-174. 
di Papua. ICG mengemukakan: "konflik antara umat beragama yaitu umat Islam dan Kristen juga bisa terjadi di Papua bila tak ditangani secara efektif. Pada 2007 kekerasan yang nyaris terjadi dapat dihindari di Manokwari dan Kaimana di propinsi Papua Barat. Tapi, tetap saja ketegangan itu menyisakan perasaan sakit hati di kedua belah pihak. Penyebab utamanya yaitu perpindahan penduduk Muslim dari daerah lain di Indonesia ke Papua yang terus berlangsung; munculnya kelompok-kelompok baru yang bersifat eksklusif di masyarakat Islam maupun Kristen yang telah memperkuat persepsi bahwa agama yang lainadalah musuh; dampak yang tidak hilang-hilang dari konflik Maluku dan pengaruh dari perkembangan diluar Papua."(http://www.crisisgtoup.org/home/ papua/index.php?page=070503)

Versi uskup Dr. Leo Laba Ladjar OFM, selaku Ketua Forum Kerukunan Umat Beragama Papua berbagai bentuk protes masyarakat Papua tersebut diakibatkan oleh"kekhawatiran perasaan orang Papua asli tentang semakin banyaknya sarana pendidikan umat Islam yang dibangun di Papua, karena orang Papua mayoritas beragama Kristen merupakan sebuah kewajaran dan tidak perlu di khawatirkan oleh pemeluk agama lain (Islam), justru harus dijadikan sebagai pemicu untuk mempercepat pembuatan perdasi dan perdasus yang dapat melindungi orang asli Papua, (17 juni 2008)."

Fenomena di atas, juga memberikan gambaran ujian terhadap upayaupaya penerapan toleransi dan pluralism. Realitas menunjukkan banyak orang atau kelompok orang (komunitas) yang tidak mentolerir toleransi itu sendiri, anpa usaha mencari jalan tengah untuk semua pihak demi terwujudnya Papua anpa diskriminasi agama. Perspektif ini tentunya akan terkesan sangat subyektif, namun sesuatu yang tak dapat disangkal jika kita merujuk pada 3pirasi para pendemopada tanggal 4 november 2008, semakin menguatkan mggapan yang di kemukakan oleh ICGbahwa "munculnya kelompok-kelompok baru yang bersifat eksklusif di masyarakat telabmemperkuat persepsi babwa agama yang lain musub" benar adanya.

Penelitian tentang kekerasan atas nama agama khususnya di provinsi Selugan oleh Christian Warta (2011), menyimpulkan bahwa sumber konflik motivasi agama dapat ditemukan di dalam radikalisme agama-agama 
akhir ini. Kerja misionaris agresif dan dakwah yang mengandung unsur kebencian telah mengacaukan hidup berdampingan secara damai. Para pendeta radikal, seperti beberapa anggota gereja evangelis dan gereja kharismatik (terutama Bethel dan Bethany) yang tidak menghormati pandangan agama lain kecuali agama mereka sendiri mungkin saja akan berpengaruh dimasa mendatang, terutama dengan latar belakang jumlah anggota mereka yang meringkat secara teratur yang membuktikan kebutuhan meluas akan kepemimpinan dan religiusitas yang ekstrem, sementara usaha-usaha para pemimpin agama di Papua untuk mencapai perdamaian masih sangat jauh dari harapan (Warta , 2011: 90-91).

Prasangka agama juga muncul dalam susunan birokrasi berupa penolakan terhadap orang beragama tertentu (Islam) untuk menjabat posisi structural. Ini yang terjadi terhadap $M$ Hatari sebagai salah satu kepala biro dalam struktur pemerintahan Provinsi Papua yang ditolak oleh sebagian kalangan hanya karena dia seorang yang beragama Islam (satu-satunya orang beragama Islam yang menduduki jabatan strategis distruktur pemerintahan Provinsi sebagai Kepala Biro keuangan), meskipun dalam pernyataan alasan penolakan tersebut lebih menekankan pada aspek pendatang. Kasus penolakan in semakin kental bernuansa agama (Kristen menolak Islam) dibandingkan dengan seorang Tedjo Suprapto (sekda Provinsi Papua) yang juga pendatang tapi beragama Kristen. Senada dengan penolakan terhadap kepala biro keuangan tersebut reistensi agama semakin nampak dalam ujud penolakan terhadap keberadaan STAIN AJ-Fatah Jayapura, yang barangkali dipandang mengancam aqidah (keyakinan) orang asli Papua.

Organisasi Isiam di Papua berupaya untuk dapat diterima baik secara kultural maupun politik atau dimana keduanya dapat bertemu. Keberadaan Majlis Muslim Papua (MMP) merupakan satu bentuk organisasi yang mendapat legitimasi dan diterima di tingkat struktural masyarakat Papua secara umum karena dianggap mewakili golongan muslim lokal (non pendatang). Sebelum terbentuknya MMP, sudah berdiri Solidaritas Muslim Papua (SMP) yang didirikan oleh sekitar 47 elit muslim Papua pada tahun 1999. Pembentukan organisasi ini tidak terlepas dari konteks kemunculan beberpa orgnaisasi lokal 
Papua dan penganut agama Kristen saat isu dan gerakan separatis merebak tahun 1999.

Pembentukan Majlis Muslim Papua ingin menunjukkan dan menolak anggapan yang selama ini lekat bahwa Islam itu identik dengan Indonesia, dan menunjukkan bahwa tidak semua penduduk Papua adalah penganut Kristen. MMP juga ingin menjembatani komunikasi antara imigran Muslim dan masyarakat Kristen Papua. Lebih dari itu, MMP bertujuan untuk lebih mengenalkan lebih dalam mengenai Islam di kalangan masyarakat pribumi Papua. MMP justru tidak menginginkan organisasi Muslim dari luar yang tidak punya akar kuat di masyarakat Papua memberikan pengaruh, khususnya Majlis Ulama Indonesia (MUI) yang dianggap memherdayakan pengaruh muslim pendatang. MMP juga berpartisipasi sebagai organisasi Islam dalam penegakkan perjuangan HAM di tanah Papua, mengurangi kemiskinan dan kesenjangan ekonomi'.

Awal tahun 2007, saat hendak mengembangkan pembangunan prasana kampus IAIN Al Fatah Jayapura (saat itu masih berstatus Sekolah Tinggi Agama Islam Negeri/STAIN) di kawasan Bumi Perkemahan Waena, muncul penolakan dari kalangan Kristiani yang dikomandani oleh Asosiasi Pendeta Indonesia (API). Adapun alasan penolakan tersebut adalah pembangunan gedung kampus itu akan semakin memajukan Islamisasi di tanah Papua. Institusi ini dianggap sebagai media modernisasi dengan akan lebih banyak memproduksi sarjana muslim (ulama), dan akan mengurangi ketergantungan terhadap ulama dari luar sehingga semakin banyak yang menjadi ulama lokal. Penolakan Asosiasi pendeta itu sangat mengecewakan organisasi muslim lokal (Majlis Muslim Papua), padahal ijin membangun kampus sudah disetujui oleh sebuah synode besar gereja GKI. MMP juga kecewa karena ternyata API adalah para pendeta yang mayoritas bukan asli Papua juga, karena lebih banyak disi oleh para pendeta dari puar Papua juga. Apalagi, kemudian Majlis Rakyat Papua (MRP) ikut ikutan menolak pembangunan kampus tersebut. Hal ini, bagi tokoh

\footnotetext{
${ }^{9}$ Lihat penelitian Cahyo Pamungkas "Muslim Papua and Special Autonomy; The Identity Contest in Papua" Journal of Indonesian Socia! Sciences and Humanities Vol. 4, 2011, pp. 133. 155 URL: http://www.kitlv-journals.nl/index.php/iissh/index
} 
Muslim lokal Papua dalam MMP sangat menyakiti umat muslim secara umum dan muslim lokal pada khususnya. Meski demikian, setelah lobby yang berat akhirnya pembangunan kampus tersebut tetap berlangsung walaupun masih ada hal yang mengganjal diantara dua kelompok agama ini (Muslim - Kristen).

\section{Tantangan Perdamaian dan Strategi Multikultural}

Pembangunan Papua yang damai terasa masih sangat panjang karena komplcksitas masalah baik dasi sisi politik, ekonomi, sosial, keamanan, seni budaya dan agama. Kompleksitas konflik juga diakibatkanbanyaknya actor yang terlibat, dan banyaknya kepentingan dalam jangka waktu yang panjang. Kondisi ini diperparah dengan kebijakan politik transaksional danpembangunan nasional yang bersifat instan dan tidak konsisten dalam implementasinya. Dalam bidang agama pula masih terdapat kelompok-kelompok yang cenderung menghambat peluang damai bisa segera diwujudkan.

Perkembangan Islam di Papua tak terelakan telah mempengaruhi kehidupan masyarakat Jayapura, perkembangannya kini dianggap mengancam pada daerah yang telah dianggap oleh sekelompok orang sebagai daerah serambi Yerusalem. Untuk hal itu perlu kiranya kita melihat strategi model di Australia yang menurut Indriana Kartini (1996), dalam jurnal tentang minoritas muslim di Australia, perlu diciptakannya suasana tidak adanya ghettoisasi dan tidak adanya politisasi atas perbedaan yang ada.

Secara substansial di Papua, khususnya di kota Jayapura riak-riak dalam masyarakat yang bersumber dari perbedaan agarna mulai muncul kepermukaan dengan ketelanjangan yang masif. Secara tegas jika dicermati, mendengar orasiorasi, membaca pernyataan-pernyataan serta melihat aksi para pendemo yang mengatasnamakan Forum Komunikasi Kristen Indonesia (FKKD) Papua tanggal 4 Agustus tahun 2008 di halaman Dewan Perwakilan Rakyat Papua di Jayapura, timbul berbagai keheranan dan keprihatinan. Konflik "agama” yang pernah terjadi di Ambon, juga berita-berita konflik agama (terutama kelompok Islam dan Kristen) mengenai pembakaran gereja atau pelarangan rumah ibadah di Jawa lewat jejaring media massa, LSM, serta mobilitas para pendakwah barangkali telah menularkan bau dan aromanya ke daratan tanah Papua di 
Jayapura. Aspirasi-aspirasi yang dilontarkan oleh para pengunjuk rasa tersebut penuh dengan nuansa sentimen agama (Kristen Menolak Islam).

Pernyataan-pernyataan yang disuarakan para pendemo tersebut antara lain, menuntut agar pemerintah daerah meninjau kembali keberadaan mushalahmushalah di seluruh tanah Papua, serta meminta kepada pemerintah untuk membatasi keberadaan masjid, madrasah, pesantren, serta untuk pembangunan sarana-sarana tersebut harus mendapatkan persetujuan dari gerejagereja setanah Papua. Bukan hanya sarana pendidikan dan peribadatan yang disasar para pendemo dalam aspirasinya, termasuk sarana perekonomian misalnya Bark Syariah, termasuk sentra ekonomi kecil, para pedagang asongan perempuan yang mengenakan jilbab, juga ikut diprotes keberadaannya, karena dianggal 3 dapat merusak dasar keyakinan masyarakat Papua yang konon katanya peradabannya dibuka dengan injil (Kristen).

Secara keseluruhan demonstrasi tersebut sesungguhnya bukan yang pertama terjadi di kota Jayapura, dengan menggunakan agama sebagai kendaraan tempurnya, secara umum hampir setiap aksi-aksi demonstrasi yang mengatasnamakan rakyat Papua, pastilah akan menggunakan Agama sebagai salah satu pilar penggerak massa. Fenomena demonstrasi di kota Jayapura ini dapat dimaklumi, karena konflik keberagamaan di Indonesia seringkali terjadi dengan menggunakan agama untuk menjustifikasi keterlibatannya dalam konflik.

Agama dipolitisir untuk tujuar-tujuan kelompok. Ketika sebuah dacrah dengan mayoritas agama $\mathrm{A}$, maka semua ditempat tersebut harus 'berdasarkan agama' A, pimpinannya harus dari agama itu, bangunan ibadah yang lain tidak boleh selain rumah ibadah agama itu. Seperti juga semangat yang diusung para pendemo tersebut, yang menginginkan semua aspek kehidupan masyarakat Papua diatur dan dikelola dengan menggunakan jargon agama tertentu (Kristen).

Isu seputar Islamisasi dan stigmatisasi orang muslim cukup mendapat perhatian dalam ajang Pemilihan Langsung Gubernaur Papua tahun 2013. Umat muslim juga dianggap sebagai konstituen yang cukup signifikan, terutama di daerah pesisir dan perkotaan. Para kandidat gubernur-wakil gubernur periode 
2013-2018 seperti layaknya pemilihan pada umumnya melakukan berbagai pendekatan terhadap warga muslim. Tidak ada satu pun dari ke enam pasangan calon gubernur dan wakil gubernur 2013-2018 yang mewakili muslim atau beragama Islam. Dalam masa kampanye terdapat gejala kampanye hitam menyangkut umat muslim yang dilarang untuk memilih salah satu pasangan. Disebutkan dalam pesan pendek (sms) berantai seperti "jika pasangan ini (Lukmen) menang maka Papua akan merdeka", " jika umat Muslim pilih pasangan ini maka masjid akan dibakar", "jangan pilih Lukmen nanti orang gunung pimpin Papua, jangan pilih Lukmen karena mereka orang gunung, serta sms lainnya". Pasangan injpun melaporkan kasus-kasus ini sebagai pelanggaran kampanye hitam dan berbau SARA. (http://www.cenderawasihpos.com/index.php?mib=berita.detail\&id=5914)

Studi sosiologi dan antropologi tentang masyarakat majemuk (plural society) selalu menggambarkan bahwa multikulturalisme merupakan sebuah ideology dari masyarakat multikultur. Yaitu masyarakat yang tersusun oleh keragaman etnik. Multikulturalisme sebagai ideology diartikan sebagai suatu bentuk respek yang bersifat mutual dari satu etnik kepada etnik yang lain, misalnya memberikan keleluasaan agar etnik lain dapat mengekspresikan budaya etniknya, dan ekspresi tersebut merupakan salah satu kontribusi penting bagi pengembangan budaya suatu bangsa (Liliweri, 2005:68-70).

Sebagai sebuah strategi komunikasi antar budaya dalam masyarakat majemuk ini, menurut Liliweri, multikuturalisme terkait erat dengan pluralism. Bahwa pluralism bertautan dengan doktrin atau "isme" tentang penyadaran individu atau kelompok terhadap kesetaraan antara beragam kebudayaan dalam suatu masyarakat majemuk. Sedangkan mulitkulturalisme bertautan dengan doktrin atau "isme" tentang penyadaran individu atau kelompok atas keberagaman kebudayaan yang pada gilirannya mempunyai kemampuan untuk mendorong lahirnya sikap toleransi, dialog, kerjasama, diantara beragam etnik dan ras.

Saya melihat, modal sosial dan budaya Papua yang plural merupakan aset danpotensi yang bisa dikelola dengan mengadopsi komunikasi multikutural ini. Di masyarakat terdapat strategi-strategi mulia warisan adat dan budaya 
leluhur yang menjadi kearifan dalam mengelola potensi konflik ditengah keragaman ini. Selayaknya, begitu pula strategi dan klaim gerakan keagamaan tak terkecuali Islam dan Kristen harus mampu menggunakan strategi kesetaraan, respek, saling menghargai dan toleransi dalambatas tertentu terhadap budayabudaya lokal.

Pada faktanya, sebgaian besar masyarakat Papua masih tcrikat crat dengan sistem adat dan kebudayaan rumpun Melanesia. Bahkan dalam kehidupan modern mereka saat ini sebagian tradisi dan adat masih diperlakukan sebagai praktek adat yang harus diikuti meskipun mereka menganut resmi Kristen ataupun Islam. Ada banyak contoh strategi budaya lokal dalam kerangka hubungan antar budaya yang selaras dengan gerakan sosial keagamaan. Strategi "Satu Tungku Tiga Batu" yang membudaya terdapat di Patipi, sebuah wilayah di Fakfak yang mayoritas penduduknya adalah muslim. Filosofi in isudah tumbuh sejak lama dan bertahan hingga saat ini.

"Satu Tungku Tiga Batu" berarti agama keluarga kami ada tiga yaitu, Kristen, Islam dan Katolik. Tiga batu ini bersatu agar tidak terjadi ketimpangan. Bahkan, kemudian istilah "Satu Tungku Tiga Batu" sudah dijadikan sebagai salah satu modal pembangunan di Fak-fak. Filosifinya sebagai saudara harus sehat, bilamana sudah bersatu, tak ada kekuatan apapun yang akan mampu melawannya. Masyarakat teluk Patipi fakfak sudah sejak dulu hidup dalam kekeluargaan yang terbangun dalam bingkai adat dan agama. Satu Tungku Tiga Batu adalah tungku masak dengan tiga batu sebagai penyangganya yang dianalogikan sebagai tiga agama; Islam, Kristen dan Katolik yang harus berperan sama guna menjaga keseimbangan memasak ${ }^{10}$.

Komitmen perdamaian sudah seringkali diikrarkan o leh berbagai komponen masyarakat Papua seperti konperensi perdamaian tanah Papua yang digelar bulan Juli 2011. Sekitar 500 orang peserta Konferensi Perdamaian Tanah Papua yang terdiri dari wakil-wakil Agama, Adat, Perempuan, Pemuda, Akademisi, Organ-organ Mahasiswa, dan kelompok resisten yang berasal dari

\footnotetext{
${ }^{10}$ Adam Iribaram, Satu Tungku Tiga Batu, Hubungan Tiga Agama di Teluk Patipi-Fakfals, http:/Letnohistori.org/satu-tungku-tiga-batu-hubungan-tiga-agama-di-teluk-patipihakfak.honl diakses pada 11 February 2013, pk」 21.30 WIB.
} 
Kabupaten/Kota Se-Tanah Papua telah berpartispasi aktif dalam konferensi yang dilaksanakan di Auditorium Universitas Cenderawasih Jayapura. Dengan mengusung tema "Mari kitong bikin Papua jadi Tanah damai", mereka berbagi pengalaman, dan saling meneguhkan satu-sama lain melalui perjumpaan, percakapan dan diskusi.

Dalam Papua Road Map, Negotiating the Past, Improving the Present and Securing the Future, tim akademis dari berbagai kalangan merekomendasikan sebuah konsep dialog "Merebus Batu". Istilah "Merebus Batu" di satu sisi merupakan ungkapan pesimis di titik nol tentang kemungkinan dialog Jakarta-Papua, tetapi di sisi lain, juga merupakan tantangan bagi para pihak yang ingin memutus siklus konflik Papua. Langkah-langkah yang direkomendasikan adalah dialog yang substansial tanpa ada pretensi mendahulukan kepentingan satu pihak saja, dialog yang melibatkanpihak asing yang netral sebagai mediator, melakukan rekonsiliasi atas akibat dari tindakan di masa lalu, pemberdayaan ekonomi, menghentikan praktik marginalisasi dan memperkuat perlindungan Hak Asasi Manusia (HAM).

\section{DAFTAR PUSTAKA}

Al Makssary, Ridwan dkk (eds), 2011, Masjid dan Pembangunan Perdamaian, CSRC UIN Jakarta

Gunawan, Asep (ed.), 2004, Artikulasi Islam Kultura, Dari Tahapan Moral ke Periode Sejarah, RajaGrafindo Persada, Jakarta.

Imarotus, S., Nur, 2011, Yang Radikal dan Yang Moderat di Papua; Membangun Institusi Perdamaian di Masjid Raya Baiturrahim Jayapura, dalam Masjid dan Pembangunan Perdamaian, editor Ridwan alMakassary dkk., CSRC UIN Jakarta.

Kamil, Sukron dan Chaedar S. Bamualim (eds.) 2007, Syariah Islam dan HAM, Dampak Perda Syariah terhadap Kebebasan Sipil, Hak-hak Perempuan, dan Non Muslim, CSRC UIN Jakarta.

Karim, Abdul dkk., 2007, Wacana Politik Islam Kontemporer, Suka PressYogyakarta 
Liliweri, Alo, 2005, Prasangka dan Konflik, Komunikasi Lintas Budaya Masyarakat Multikultur, LKiS Yogyakarta

Warta, Christian. 2011. 'Perkembangan Masalah Agama di Papua : sengketa Antara Agama dan Pencegahan Konflik' dalam Kegalauan Identitas, Agama, Etnisitas dan Kewaryanegaraan pada Masa Pasca-Orde Baru. Grasindo: Jakarta

Widjojo, Muridan S. (ed.) 2009, Papra Road Map, Negotiating the Past, Improving the Present and Securing the Future, LIPI, Yayasan TIFA, dan Yayasan Obor Indonesia, Jakarta.

Zein, Kurniawan dkk. (eds.), 2001, Syari'at Islam Yes, Syariat Islam No, Dilema Piagam Jakarta dalam Amandemen UUD 1945, Paramadina Jakarta

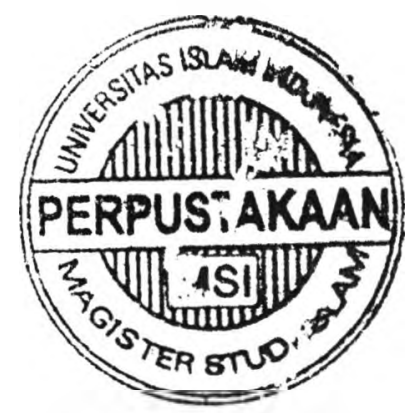

